\title{
DOI: https://doi.org/10.24297/jaa.v10i0.8149
}

\section{Heavy metals concentrations in bee products collected from contaminated and non-contaminated areas from Upper Egypt Governorates}

\author{
N.S.Omran', M.O.M.Omar², M.H. Hussein ${ }^{2}$ and M.M. Abd-Allah ${ }^{1}$ \\ ${ }^{1}$ Faculty of Agriculture, Sohag University, Egypt. \\ ${ }^{2}$ Faculty of Agriculture, Assiut University, Egypt.
}

Nageh.ahmed@agr.sohag.edu.eg.

\begin{abstract}
Twenty fresh clover honey, ten beeswax and ten bee bread samples represented contaminated and noncontaminated areas were collected directly from the apiaries during 2015 .The aim of this study was to evaluate the presence of toxic metals ( Lead $(\mathrm{Pb})$, Cadmium (Cd), Iron (Fe), Copper (Cu) and Zinc ( $\mathrm{Zn})$ ) in honey, beeswax and bee bread stored inside honey bee colonies. The highest lead contents $(0.5488 \mathrm{mg} / \mathrm{kg})$ was estimated in honey samples collected from industrialized area The lowest $\mathrm{Pb}$ content were estimated in honey samples collected from rural area $(0.5096 \mathrm{mg} / \mathrm{kg})$. The lowest $\mathrm{Cd}$ concentration $(0.0961 \mathrm{mg} / \mathrm{kg})$. However, the highest content of $\mathrm{Cd}(0.1042 \mathrm{mg} / \mathrm{kg})$ was recorded in honey samples collected from urbanized areas. High concentration of $(\mathrm{Cu})$ was estimated in honey samples collected from apiaries located in industrialized area $(0.0757 \mathrm{mg} / \mathrm{kg})$ while the lowest were recorded in rural area $(0.0432 \mathrm{mg} / \mathrm{kg})$. Zn occurred in low concentration in honey samples The highest value was recorded in honey samples from rural area (0.241) $\mathrm{mg} / \mathrm{kg}$ and the lowest in honey samples from apiaries located in Reclaimed soils $(0.185) \mathrm{mg} / \mathrm{kg}$. Heavy metal concentrations of $\mathrm{Pb}, \mathrm{Cd}, \mathrm{Fe}, \mathrm{Cu}$ and $\mathrm{Zn}$ in beeswax samples collected from contaminated and noncontaminated areas were $1.388,0.194,16.696,0.619$ and $4.606 \mathrm{mg} / \mathrm{kg}$. While the averages of heavy metal concentrations in non contaminated area decreased to $1.175 ; 0.160 ; 15.466 ; 0.391$ and $2.520 \mathrm{mg} / \mathrm{kg}$, respectively. Contamination in bee bread samples showed that lead concentration $(1.094 \mathrm{mg} / \mathrm{kg}$ to 1.338 $\mathrm{mg} / \mathrm{kg}$ ) was detected in bee bread samples collected from honey bee colonies located in non-contaminated areas and samples collected from( industrialized and urban areas).
\end{abstract}

Keywords: heavy metal, bee products, contaminated areas, bee honey, beeswax, bee bread.

\section{Introduction}

The most important parameters to evaluate honey quality are floral origins, the area of production, freshness and safety. Like any other foods, honey is prone to various types of contaminations (Al-Waili et al., 2012) but it should be free of any chemical contaminants and safe for human consumption (Tisipi et al., 1999).

Some apiaries are located in areas exposed to different kinds and level of pollution. Honey bees may forage over a distance of several kilometers from the hives and they effectively sample the environment for contaminats in plants, soil and the atmosphere (Przybylowski and Wilczynska, 2001). Large concentrations of heavy metals were found in bee honey from hives located in industrial areas. This is why honey and other bee products are considered good materials for monitoring environmental contaminations (Omran, 2017 and Omar, 1994).

The present investigation has been carried out to monitor the impact of environmental pollution by heavy metals on quality of bee products. 


\section{Material and Methods}

The present investigation was conducted in Plant Protection Department, Faculty of Agriculture, Sohag University. The experiments were carried out during season 2015 to evaluate Heavy metals concentrations in bee products collected from contaminated and non-contaminated areas under Upper Egypt region.

\section{Heavy metals determination in bee products:}

\subsection{Area of study:}

Twenty commercial apiaries distributed in four governorates in Upper Egypt were selected (Table 1). Every five apiaries were located in one of the following areas:
a. Rural agricultural area.
b. Reclaimed soils.
C. Industrialized area.
d. Urbanized and traffic area.

The first and second groups represented non-contaminated areas and third and fourth groups represented contaminated areas.

\subsection{Bee products sampling:}

For evaluating the contamination of honey, beeswax and bee bread with heavy metals, samples from each product were collected. Four hives were chosen randomly in each apiary. Single sample of fresh clover honey, stored bee bread and beeswax were taken. The material was collected in June, 2015 after clover honey flow.

Fresh honey samples $(50 \mathrm{gm})$ were taken directly from the combs by squeezing. Upon collection each honey samples was placed into dark glass bottle and labeled.

Table (1): Locations of tested honey bee products for determining heavy metals.

\begin{tabular}{|c|l|l|l|l|}
\hline Location & Governorate & District & No. of apiary & No. of samples \\
\hline \multirow{3}{*}{ Rural area } & $\begin{array}{l}\text { Sohag } \\
\text { Qena } \\
\text { Luxor }\end{array}$ & $\begin{array}{l}\text { Johayna } \\
\text { Qena } \\
\text { Esna }\end{array}$ & 2 & 1 \\
\hline Reclaimed soils & $\begin{array}{l}\text { Sohag } \\
\text { Qena }\end{array}$ & $\begin{array}{l}\text { El-Kowther } \\
\text { Nagada }\end{array}$ & 2 & 5 \\
\hline \multirow{2}{*}{$\begin{array}{l}\text { Industrialized } \\
\text { Urban and } \\
\text { traffic }\end{array}$} & $\begin{array}{l}\text { Luxor } \\
\text { Aswan }\end{array}$ & $\begin{array}{l}\text { Sohag } \\
\text { Komant }\end{array}$ & 2 & 5 \\
\hline Total & Luxor & $\begin{array}{l}\text { El-Balina } \\
\text { El-Qona }\end{array}$ & 3 & 5 \\
\hline
\end{tabular}


Beeswax samples were taken from freshly formed combs in the same season. A piece of wax $(10 \times 10 \mathrm{~cm})$ was taken from empty wax comb from each hive. When samples were brought back to the laboratory all wax samples from the same apiary were combined.

Bee bread samples were collected by cutting a $6 \times 6 \mathrm{~cm}$ piece of comb containing stored pollen using a disposable plastic knife and placed in polyethylene page.

All samples were transported to the laboratory and frozen at $-20^{\circ} \mathrm{C}$ until analysis. The total number of samples collected was 25 samples for each product.

\subsection{Heavy metals determination:}

The concentrations of heavy metals $(\mathrm{Pb}, \mathrm{Cd}, \mathrm{Fe}, \mathrm{Cu}$ and $\mathrm{Zn}$ ) were determined by an Atomic Absorption Spectrophotometer (AAnalyst, 400, Perkin Elmer, USA) according to AOAC guidelines (1995) in laboratories of Science Faculty, Sohag University.

The metals concentrations in bee products (honey, wax, bee bread) samples were quantified against standard solutions of known contents which were analyzed concurrently. The sample concentrations of heavy metals were calculated in $\mathrm{mg} / \mathrm{kg}$.

\subsection{International standards for heavy metals in bee products}

\section{a. Honey standards:}

There is international standards for honey in terms of cadmium, lead, copper, iron and zinc contents. According to FAO/WHO, 1996 for copper $\left(0.1-50 \mathrm{mg} \mathrm{kg}^{-1}\right)$; iron (1.5-15 mg kg-1); lead (0.1-2.0 mg kg-1) and zinc $\left(<5.0 \mathrm{mg} \mathrm{kg}^{-1}\right)$ levels. According to Turkish Food Codex, 2006. The maximum levels of cadmium, copper, lead, zinc, must be $0.1,2.0,1.0$ and $5.0 \mathrm{mg} \mathrm{kg}^{-1}$ respectively.

\section{b. Specification of heavy metal in beeswax:}

Pursuant to the European legislation beeswax specification values were set to $5 \mathrm{mg} \mathrm{kg}-1$ for Pb; $3 \mathrm{mg} \mathrm{kg}-1$ for AS and $1 \mathrm{mg} \mathrm{kg}-1$ for $\mathrm{Hg}$ (Directive, 2016). The FAO/Who Expect committee on food additives also set a concentration of $2 \mathrm{mg} \mathrm{kg}-1$ for $\mathrm{Pb}$ in wax and proposed a maximum residue limit (MRL) for the EU of $1 \mathrm{mg} \mathrm{kg}$ 1 (European commission (EC) 2001). The committee of the European food safety authority (EFSA). Formicki et al. (2013) recommended that the specification for $\mathrm{Pb}$ should be set as low as possible due to its possible toxic effects.

\subsection{Statistical analysis:}

Data are expressed as mean values \pm S.D. of five replicates and statistically analyzed by analysis of variance (ANOVA) and t-test. The statistical analysis were significant when $\mathrm{P}<0.05$ (Steel and Torrie, 1980).

\section{Results and Discussion}

\section{Assessment of heavy metals contamination in honey bee products:}

Honey bee products obtained from twenty commercial apiaries located in contaminated and noncontaminated area in Upper Egypt region. All samples were subjected to determine the residual levels of Lead $(\mathrm{Pb})$, Cadmium ( $\mathrm{Cd})$, Iron ( $\mathrm{Fe})$, Copper ( $\mathrm{Cu}$ ) and Zinc $(\mathrm{Zn})$ in honey, beeswax and bee bread stored inside honey bee colonies. 


\section{Heavy metals content in honey:}

Results of heavy metals detection in honey samples were presented as mean values \pm standard deviations of all the samples collected from different locations according to the source of contamination.

\section{a- Lead and cadmium content:}

Lead $(\mathrm{Pb})$ was found in all the tested honey samples collected from different areas. High means of $\mathrm{Pb}$ content $(0.5488$ and $0.5120 \mathrm{mg} / \mathrm{kg})$ were estimated in honey samples collected from the contaminated area (industrialized and urbanized area), Table (2). The lowest means of $\mathrm{Pb}$ content were estimated in honey samples collected from rural and Reclaimed soils $(0.5096$ and $0.5099 \mathrm{mg} / \mathrm{kg}$ ), respectively. Honey samples collected from industrialized area had the highest lead content with a significance difference with all other locations. A positive deviation percentage $(+7.14 \%)$ was recorded when the lead content of honey samples collected from industrialized area comparing with that of honey samples collected from rural area.

Also, it is important to analyses the cadmium content in honey samples in view of its toxicity for human, as well as the fact that cadmium (Cd) can be transported through the root system of plants to the nectar in flowers.

Analysis of variance indicated that highly significant differences in cadmium ( $\mathrm{Cd}$ ) content between honey samples collected from the study apiaries (Table 3).

Table (2): Lead content of honey samples collected from contaminated and non-contaminated areas in Upper Egypt during 2015 season.

\begin{tabular}{|c|c|c|c|c|}
\hline \multirow{2}{*}{\multicolumn{2}{|c|}{ Location }} & \multicolumn{2}{|c|}{$\mathrm{Pb}$ concentration $(\mathrm{mg} / \mathrm{kg})$} & \multirow{3}{*}{$\begin{array}{l}\text { Deviation \% } \\
-\end{array}$} \\
\hline & & \multirow{2}{*}{\begin{tabular}{|l|} 
Min - Max. \\
$0.4704-0.5508$
\end{tabular}} & \multirow{2}{*}{\begin{tabular}{|l|} 
Mean \pm Sd \\
$0.5096 \pm 0.031 d$
\end{tabular}} & \\
\hline Non-contaminated & Rural area & & & \\
\hline areas & Reclaimed soils & $0.4866-0.5247$ & $0.5099 \pm 0.023 c$ & $+0.06 \%$ \\
\hline \multirow[b]{2}{*}{ Contaminated areas } & Industrialized area & $0.5262-0.5730$ & $0.5488 \pm 0.020 a$ & $+7.14 \%$ \\
\hline & $\begin{array}{ll}\text { Urbanized } & \text { (motor } \\
\text { traffic) } & \end{array}$ & $0.4950-0.5334$ & $0.5120 \pm 0.024 b$ & $+0.47 \%$ \\
\hline \multicolumn{2}{|l|}{ LSD 5\% } & \multicolumn{3}{|l|}{$>0.001$} \\
\hline
\end{tabular}

Means within the same column followed by the same letter do not differ significantly at $5 \%$ level of probability.

Table (3): Cadmium content of honey samples collected from contaminated and Non-contaminated areas in Upper Egypt during 2015 season.

\begin{tabular}{|c|c|c|c|c|}
\hline \multirow{2}{*}{\multicolumn{2}{|c|}{ Location }} & \multicolumn{2}{|c|}{ Cd concentration $(\mathrm{mg} / \mathrm{kg})$} & \multirow{3}{*}{$\begin{array}{l}\text { Deviation \% } \\
-\end{array}$} \\
\hline & & \multirow{2}{*}{$\begin{array}{l}\text { Min - Max. } \\
0.0846-0.1032\end{array}$} & \multirow{2}{*}{$\begin{array}{l}\text { Mean } \pm \text { Sd } \\
0.0961 \pm 0.001 d\end{array}$} & \\
\hline Non- & Rural area & & & \\
\hline $\begin{array}{l}\text { contaminated } \\
\text { areas }\end{array}$ & Reclaimed soils & $0.0960-0.1014$ & $0.0982 \pm 0.002 c$ & $+2.19 \%$ \\
\hline \multirow{2}{*}{$\begin{array}{l}\text { Contaminated } \\
\text { areas }\end{array}$} & Industrialized area & $0.0966-0.1050$ & $0.1012 \pm 0.003 b$ & $+5.31 \%$ \\
\hline & Urbanized (motor & $0.1002-0.1068$ & $0.1042 \pm 0.001 \mathrm{a}$ & $+8.43 \%$ \\
\hline
\end{tabular}




\begin{tabular}{|l|l|l|l|l|}
\hline & traffic) & & & \\
\hline LSD 5\% & $>0.001$ & \\
\hline
\end{tabular}

\footnotetext{
- Means within the same column followed by the same letter do not differ significantly at $5 \%$ level of probability.
}

Generally, the lowest cadmium content was estimated in honey samples collected from rural apiaries $(0.0961$ $\mathrm{mg} / \mathrm{kg}$ ). However, the highest content was recorded in honey samples collected from industrialized area $(0.1012 \mathrm{mg} / \mathrm{kg})$ followed by honey samples collected from urbanized area $(0.1042 \mathrm{mg} / \mathrm{kg})$. The mean content of Cd obtained concentrated under the standard limit $(0.1 \mathrm{mg} / \mathrm{kg})$.

Cadmium (Cd) content was positively correlated with Lead $(\mathrm{Pb})$ content in honey samples collected from different locations (Fig. 11).

It is evident that present data obtained are similar as those of honey samples tested in Turkey (Tuzen and Saylak, 2005), in Spain (Gonzâlez Paramâs et al., 2000), in Poland (Przybylowski and Wilczynska, 2001).

The amount of $\mathrm{Pb}$ in honey depended on the location of the apiaries, where the internal combustion engines are the main source of contamination. In urban area, the industries release some gases with containing lead as one of the contaminant contents. In the similar $\mathrm{Pb}$ way, the fumes released from gasoline combustion in vehicles also acts as a source of lead in environment which can be deposited in soil water and plants and later enter humans through food chain. Lead can contaminate air or nectar (Bogdanov, 2006). Also, it was established that the concentration such elements as cadmium and lead relatively reach high value in samples coming from polluted areas in Europe (Fodor and Molnar, 1993; Pieter et al., 1993).

According to the pollution standards, values of heavy metals recorded by the Codex Alimentarius Commission indicated that the maximum $\mathrm{Pb}$ value allowed in sweet nutrient such as sugar and honey should be below 0.3 $\mu \mathrm{g} / \mathrm{g}$. Also $0.3 \mu \mathrm{g} / \mathrm{g}$ is the maximum permitted limits for $\mathrm{Cd}$. The reason behind this may be the use of inferior grade plastic containers for honey storage (Chandrama et al., 2014).

\section{b- Iron content:}

When comparing the results of tested honey samples collected from different locations in Upper Egypt region, iron contents in honey samples collected from contaminated and non-contaminated areas were differed significantly (Table 4). Iron contents of honey collected from rural and Reclaimed soils were 2.201 and 2.073 $\mathrm{mg} / \mathrm{kg}$, respectively. However, Iron (Fe) content values of honey samples collected from urbanized or industrialized area (Armant and Komombo districts) increased to 2.506 and $2.422 \mathrm{mg} / \mathrm{kg}$, respectively. Special attention should be also paid to increase iron content in urbanized and industrialized areas. Also, the $\mathrm{Fe}$ concentration in honey depends on the flora of a particular area having a source of iron compound. The concentration values of iron ranged from 2.074 to $2.506 \mathrm{mg} / \mathrm{kg}$ in Upper Egypt honeys in the present study. These concentration were within the concentration values previously recorded by Khan et al. (2006) and Tiwari et al. (2016). A positive deviation percentages (10.04 and 13.86\%) were calculated among honey samples collected from industrialized and urbanized areas and rural area.

Iron is essential element for biological systems. It can have a harmful effect when its concentration exceed in food. The excess of iron in food is correlated in principal, with degenerative disease, such as Parkinson and Alzheimer (Mann et al., 1994). 


\section{c- Copper content:}

Results of copper $(\mathrm{Cu})$ detection was presented in Table (5). Copper was found in all tested honey samples. High Cu content was estimated in honey samples collected from contaminated area (industrialized and urban areas). The values were 0.0756 and $0.0542 \mathrm{mg} / \mathrm{kg}$, respectively. However, the lowest values were recorded in rural and Reclaimed soils $(0.0432$ and $0.0434 \mathrm{mg} / \mathrm{kg})$. The lowest values of non contaminated areas were differed significantly with that of the contaminated areas. However, the present values of copper recorded in honey samples collected from Upper Egypt region were under standard level. None of any honey samples contained toxic quantities of copper as recorded in Codex, 2001. The present results were similar to previously values recorded in Brazilian and New Zeland honey by Batista et al. (2012) and Vanhanen et al. (2011).Copper is an essential element for humans nutrition.

Table (4): $\quad$ Iron content of honey samples collected from non-contaminated and contaminated areas in Upper Egypt during 2015 season.

\begin{tabular}{|l|l|l|l|l|}
\hline \multirow{2}{*}{ Location } & \multicolumn{2}{|l|}{ Fe concentration $(\mathrm{mg} / \mathrm{kg})$} & \multirow{2}{*}{ Deviation \% } \\
\cline { 3 - 5 } \multicolumn{2}{|l|}{} & Min - Max. & Mean \pm Sd & \\
\hline $\begin{array}{l}\text { Non- } \\
\text { contaminated } \\
\text { areas }\end{array}$ & Rural area & $2.105-2.289$ & $2.201 \pm 0.062 \mathrm{ab}$ & - \\
\cline { 2 - 5 } & Reclaimed soils & $1.810-2.368$ & $2.073 \pm 0.1142 \mathrm{~b}$ & -5.82 \\
\hline \multirow{2}{*}{$\begin{array}{l}\text { Contaminated } \\
\text { areas }\end{array}$} & Industrialized area & $2.324-2.606$ & $2.422 \pm 0.120 \mathrm{a}$ & $+10.04 \%$ \\
\cline { 2 - 5 } & $\begin{array}{l}\text { Urbanized (motor } \\
\text { traffic) }\end{array}$ & $2.006-2.959$ & $2.506 \pm 0.241 \mathrm{a}$ & $+13.86 \%$ \\
\hline LSD 1\%, 5\% & $0.32,0.453$ & & \\
\hline
\end{tabular}

- Means within the same column followed by the same letter do not differ significantly at $5 \%$ level of probability.

Table (5): Copper content of honey samples collected from contaminated and Non- contaminated areas in Upper Egypt during 2015 season.

\begin{tabular}{|c|c|c|c|c|}
\hline \multirow{2}{*}{\multicolumn{2}{|c|}{ Location }} & \multicolumn{2}{|c|}{ Cu concentration $(\mathrm{mg} / \mathrm{kg})$} & \multirow{3}{*}{$\begin{array}{l}\text { Deviation \% } \\
-\end{array}$} \\
\hline & & \multirow{2}{*}{$\begin{array}{l}\text { Min - Max. } \\
0.0432-0.0552\end{array}$} & \multirow{2}{*}{$\begin{array}{l}\text { Mean } \pm \text { Sd } \\
0.0432 \pm 0.003 c\end{array}$} & \\
\hline Non- & Rural area & & & \\
\hline areas & Reclaimed soils & $0.0402-0.0468$ & $0.0434 \pm 0.012 c$ & $+0.46 \%$ \\
\hline \multirow{2}{*}{$\begin{array}{l}\text { Contaminated } \\
\text { areas }\end{array}$} & $\begin{array}{l}\text { Industrialized } \\
\text { area }\end{array}$ & $0.0726-0.0816$ & $0.0756 \pm 0.022 a$ & $+75.00 \%$ \\
\hline & $\begin{array}{l}\text { Urbanized } \\
\text { (motor traffic) }\end{array}$ & $0.0438-0.0720$ & $0.0542 \pm 0.023 b$ & $+20.83 \%$ \\
\hline \multicolumn{2}{|l|}{ LSD 5\% } & \multicolumn{3}{|l|}{$>0.001$} \\
\hline
\end{tabular}

- Means within the same column followed by the same letter do not differ significantly at $5 \%$ level of probability. 


\section{d- Zinc content:}

Similar to the other elements, zinc occurred in low concentration in honey. The lowest value was estimated in honey samples collected from apiaries located in Reclaimed soils followed by that located in rural areas. Analysis of honey samples showed a low zinc contents (range from 0.185 to $0.241 \mathrm{mg} / \mathrm{kg}$ ) Table (6). The highest zinc content was determined in honey samples collected from rural area $(0.241 \mathrm{mg} / \mathrm{kg})$. Some agricultural practices as using organic fertilizations in rural areas to increase plant growth and crop yield is the main source of $\mathrm{Zn}$ in honey. Also, instruments used in apiaries are also responsible for $\mathrm{Zn}$ concentration in honey. The present finding were lower than earlier results $(0.06-0.216 \mathrm{mg} / \mathrm{kg})$ reported by Achudume and Nwafiri (2008).

Zinc is an essential element for man but the high level of dietary zinc can cause anemia and decreased copper and iron absorption (WHO, 1982).

Honey can be a good source of major trace elements needed by human. Metals such as $\mathrm{Fe}, \mathrm{Cu}, \mathrm{Zn}$ are essential for humans. They may play an important role in a number of biochemical processes (Garrett et al., 1998). Some of them are present at the trace level being toxic if they exceed safety levels (Przybylowski and Wilczynska, 2001).

Table (6): Zinc content of honey samples collected from contaminated and Non-contaminated areas in Upper Egypt during 2015 season.

\begin{tabular}{|l|l|l|l|l|}
\hline \multirow{2}{*}{ Location } & \multicolumn{2}{l|}{ Zn concentration $(\mathrm{mg} / \mathrm{kg})$} & \multirow{2}{*}{ Deviation \% } \\
\cline { 3 - 4 } & Min - Max. & Mean \pm Sd & \\
\hline \multirow{2}{*}{$\begin{array}{l}\text { Non-contaminated } \\
\text { areas }\end{array}$} & Rural area & $0.206-0.300$ & $0.241 \mathrm{a}$ & - \\
\cline { 2 - 5 } & Reclaimed soils & $0.201-0.209$ & $0.208 \mathrm{ab}$ & $-13.69 \%$ \\
\hline $\begin{array}{l}\text { Contaminated } \\
\text { areas }\end{array}$ & $\begin{array}{l}\text { Industrialized } \\
\text { area }\end{array}$ & $0.210-0.267$ & $0.213 \mathrm{ab}$ & $-11.62 \%$ \\
\cline { 2 - 4 } & $\begin{array}{l}\text { Urbanized (motor } \\
\text { traffic) }\end{array}$ & $0.167-0.209$ & $0.185 \mathrm{~b}$ & $-23.24 \%$ \\
\hline LSD 1\%, 5\% & $0.044,0.061$ & & \\
\hline
\end{tabular}

- $\quad$ Means within the same column followed by the same letter do not differ significantly at $5 \%$ level of probability.

Chemical elements in honey samples throughout the world vary in term of concentrations and are also influenced by environmental pollution.

The present study shows the good quality and safety of honey produced from Upper Egypt governorates. The low metal content $(\mathrm{Fe}, \mathrm{Cu}, \mathrm{Zn}$ ) of all honey samples collected from different locations (rural and industrialized areas) are probably due to the small development of industrial activities.

The low metal concentrations found of Upper Egypt honeys are lower than residual levels obtained by other authors from other countries, Turkey (Erbilir and Erdogrul, 2005), Spain (Frias et al., 2008) and similar to that obtained in other regions of Italy (Ruschioni et al., 2013) but higher than in France (Lambert et al., 2012).

\section{Heavy metal content in beeswax:}

Values of heavy metal concentrations in beeswax samples collected from contaminated and non contaminated areas in Upper Egypt region have been presented in Table (7) . The concentration averages of $\mathrm{Pb}, \mathrm{Cd}, \mathrm{Fe}, \mathrm{Cu}$ 
and $\mathrm{Zn}$ found in wax samples collected from industrialized and urbanized areas were $1.388 ; 0.194 ; 16.696$; $0.619 ; 4.606 \mathrm{mg} / \mathrm{kg}$, while the averages of metal concentration determined in honey samples collected from apiaries located in rural and Reclaimed soils were $1.175 ; 0.160 ; 15.466 ; 0.391 ; 2.520 \mathrm{mg} / \mathrm{kg}$, respectively.

Lead and cadmium contents were found to be significantly higher in wax collected from urbanized area (Table 19). Presence of cadmium in wax samples is under the maximum permitted limit, the concentration of cadmium was noticed to be lower than obtained by Chandrama et al. (2014). In Urbanized areas, the industries release some gases containing lead as one of the content. In the similar way, the fumes released from

Table (7): Heavy metal concentrations in beeswax samples collected from contaminated and noncontaminated areas of Upper Egypt region, 2015 season.

\begin{tabular}{|c|c|c|c|c|}
\hline \multirow{2}{*}{ Metal } & \multicolumn{2}{|c|}{$\begin{array}{l}\text { Mean of metal concentration }(\mathrm{mg} / \mathrm{kg}) \\
\pm \mathrm{SD}\end{array}$} & \multicolumn{2}{|l|}{ t-test } \\
\hline & Non contaminated areas & $\begin{array}{l}\text { Contaminated } \\
\text { areas }\end{array}$ & t-value & $\operatorname{Sig}(P)$ \\
\hline $\mathrm{Pb}$ & $1.75 \pm 0.057$ & $1.388 \pm 0.026$ & $8.60^{\star \star}$ & 0.001 \\
\hline $\mathrm{Cd}$ & $0.160 \pm 0.004$ & $0.194 \pm 0.004$ & $11.80^{* \star}$ & 0.0003 \\
\hline $\mathrm{Fe}$ & $15.466 \pm 3.671$ & $16.696 \pm 2.258$ & 0.71 & 0.520 \\
\hline $\mathrm{Cu}$ & $0.391 \pm 0.096$ & $0.620 \pm 0.123$ & 2.28 & 0.060 \\
\hline$Z n$ & $2.052 \pm 0.757$ & $4.606 \pm 0.510$ & $4.79^{\star \star}$ & 0.009 \\
\hline
\end{tabular}

\section{** Highly significant.}

gasoline combustion in Vehicles also acts as a source of lead in environment which can be deposited in soil, water and plants and leater enter humans through food chain. Lead can contaminate air or nectar (Bogdanov, 2006 and Bogdanov et al., 2007).

\section{Heavy metal contents in bee bread:}

Results of heavy metal contaminations in bee bread samples are presented in Table (8) as mean values \pm standard deviation of all analyzed bee bread samples collected from both contaminated and noncontaminated areas and illustrated .

The results show that low lead concentration $(1.094 \mathrm{mg} / \mathrm{kg}$ ) was detected in bee bread collected from honey bee colonies located in non-contaminated areas. However, this value increased significantly to $1.338 \mathrm{mg} / \mathrm{kg}$ in samples collected from apiaries located in industrialized and urbanized areas.

The recorded cadmium concentration in bee bread samples collected from honey bee colonies located in rural area was $0.146 \mathrm{mg} / \mathrm{kg}$, while this value increased significantly to $0.182 \mathrm{mg} / \mathrm{kg}$ when honey bee colonies located in industrialized and urbanized areas. Also, iron and copper concentrations values of samples from industrialized areas increased insignificantly with the contents of rural samples.

The lowest proportion of zinc was found in rural area $(1.614 \mathrm{mg} / \mathrm{kg})$ while the highest proportion $(2.58 \mathrm{mg} / \mathrm{kg})$ was found in bee bread samples stored in honey bee colonies located in industrialized area with significant difference between the two locations.

Zinc is an essential element that occurs in the human body in larger quantities. Its concentration in human is about $1.8 \mathrm{~g}$. According to the RDA (1980), allowed daily allowance for men is $15 \mathrm{mg}$ and for women $12 \mathrm{mg}$. 
The obtained results support the hypothesis that metal pollution contaminate pollen was more than enters honey (Formicki et al., 2013).

Table (8): Heavy metals concentrations in bee bread samples collected from contaminated and noncontaminated areas of Upper Egypt region in 2015 season.

\begin{tabular}{|c|c|c|c|c|}
\hline \multirow{2}{*}{ Metal } & \multicolumn{2}{|c|}{$\begin{array}{l}\text { Mean of metal concentrations }(\mathrm{mg} / \mathrm{kg}) \\
\pm \mathrm{SD}\end{array}$} & \multicolumn{2}{|l|}{ t-test } \\
\hline & Non contaminated areas & $\begin{array}{l}\text { Contaminated } \\
\text { areas }\end{array}$ & t-value & $\operatorname{Sig}(P)$ \\
\hline $\mathrm{Pb}$ & $1.094 \pm 0.063$ & $1.338 \pm 0.023$ & $8.90 * *$ & 0.001 \\
\hline $\mathrm{Cd}$ & $0.146 \pm 0.010$ & $0.182 \pm 0.009$ & $6.09 * *$ & 0.002 \\
\hline $\mathrm{Fe}$ & $9.958 \pm 2.850$ & $14.952 \pm 1.647$ & 2.50 & 0.07 \\
\hline $\mathrm{Cu}$ & $0.265 \pm 0.038$ & $0.342 \pm 0.068$ & 2.30 & 0.08 \\
\hline $\mathrm{Zn}$ & $1.614 \pm 0.205$ & $2.58 \pm 0.684$ & $4.00^{* *}$ & 0.02 \\
\hline
\end{tabular}

** Highly significant.

\section{References}

1. Achudume, A.C. and b.N. (2008). The ecological assessment of metals in local brands of honey in Southwest Nigeria. Afr. J. Agric. Res., 5 (8): 2008-2010.

2. AOAC (1995). Official methods of analysis $\left(16^{\text {th }}\right.$ ed, Vol. II Washington, DC USA Association of Official Analytical Chemists.

3. Al-Waili, N.; K. Salom; A. Al-Ghamdi; M.J. Ansari (2012). Antibiotic, pesticide and microbial contaminants of honey: human health hazards. Scientific World J. Article ID 930849, p. 9.

4. Batista, B.L.; L.R.S. dasilva; B.A. Rocha; J.L. Rodriguez; A.A. Baretta-Silva; T.O. Bonates, et al. (2012). Multi-element determination in Brazilian honey samples by inductively coupled plasma mass spectrometry and estimation of geographic origin with data mining techniques. Food Research International, 49: 209-215.

5. Bogdanov, S. (2006). Contaminants of bee products. Apidologie, 37: 1-18.

6. Bogdanov, S.; M. Haldimann; W. Luginbuhl and P. Gallmann (2007). Minerals in honey environmental, geographical and botanical aspects. J. Apic. Res. 46: 269-275. Available from: http://www.bee-hexagon.net; Accessed 2015.

7. Chandrama, S.; R. Shubharani and V. Sivaram (2014). Assessment of heavy metals in honey by atomic absorption spectrometer. WJPPS, 3(8): 509-515.

8. Erbilir, F. and O. Erdogrul (2005). Determination of heavy metals in honey in Kahramanmara City, Turkey. Environ. Monit. Assess., 109: 181-187. http://dx.doi.org/10.1007/s10661-005-5848-2.

9. Fodor, P. and E. Molnar (1993). Honey as an environmental indicator; effect of sample preparation on trace element determination by ICP-AES. Microchim. Acta 112, 113.

10. Formicki, G.; A. Gren; A. Stawarz; B. Zysk and A. Gal (2013). Metal content in honey, propolis, wax and bee pollen and implications for metal pollution monitoring. Pol. J. Environ. Stud., 22 (1): 99-106.

11. Frias, J.; C. Rubio; T. Gonzalez-Iglesias; A.J. Gutierrez; D. Gonzalez-Weller and Hardisson A. (2008). Metals in fresh honeys from Tenerife Island, Spain. Bull. Environ. Contam. Toxicol., 80 (1): 30-33. 
12. Garrett, E.S.; M.L. Jahncke and E.A. Cole (1998). Effects of Codex and GATT. Food Control, 9 (2): $177-$ 182.

13. Gonzâlez Paramâs, A.M.; J.A. Gomez Barez; R.J. Garcia-Villanova; T.R. Pala; R.A. Albajar and J.S. Sanchez (2000). Geographical discrimination of honeys by using mineral composition and common chemical quality parameters. Journal of the Science of Food and Agriculture, 80: 157-165.

14. Khan, M.N.; M. Qaiser; S.M. Raza and M. Rehman (2006). Physiochemical properties and pollen spectrum of imported and local samples of blossom honey from the Pakistani market. Int. J. Food Sci. Technol., 41: 775-781.

15. Lambert, O.; M. Piroux; S. Puyo; C. Thorin; M. Larhantec; F. Delbac and H. Pouliquen (2012). Bees honey and pollen as sentinels for lead. Environ. Pollut. 170: 254-9. http://dx.doi.org/10.1016/j. envpol.2012.07.012.

16. Mann, I.V.M., et al., complex (1994). Iron and Ferritin in Pakistan's disease substantia Nigera, Ann. of Neurology, 36 (6): 876-881.

17. Omar, M.O.M. (1994). Level of some heavy metals in honey samples collected from Upper Egypt. The Second Saudi Symposium on Food and Nutrition (7-10 November, 1994).

18. Omran, N. S. ; I.S. Mohamed and M. S. O.Mabrouk. (2017). The bee honey as an indicator to environmental pollutions by heavy metals in Sohag, South Egypt, Egypt. Participate in the $32^{\text {nd }}$ annual meeting of the Saudi Biological Society in Makkah Al-Mukarramah, Saudi Arabia on April 18-20

19. Przybylowski, P. and A. Wilczynska (2001). Honey as an environmental marker. Food Chem. 74: 289291

20. Pieter, R.; S. Fortaner and E. Sabbioni (1993). Use of chelex 100 resin in preconcentration and radiochemical separation neutron activation analysis applied to environmental toxicology and biomedical research. J. Trace Micro. Tech. 11, 235.

21. RDA, Recommended Dietary Allowances (1980). Recommended Dietary Allowances 9. Ed. National Academy of Science, Washington, D.C. pp. 43.

22. Ruschioni, S.; P. Riolo; R.L. Minuz; M. Stefano; M. Cannella; C. Porrini and N. Isidoro (2013). Biomonitoring with honeybees of heavy metals and pesticides in nature reserves of the Marche Region (Italy). Biol. Trace Elm. Res., 154 (2): 226-33. hhtp://dx.doi.org/10. 1007/s12011-9013-9732-6.

23. Steel, R.G.D. and J.H. Torrie (1980). Principles and Procedures of Statistic. Ms-Graw-Hill, New York, p. 173.

24. Tisipi, D.; M. Trianlafyllon and A. Hiskia (1999). Determination of organochlorin pesticides residues in honey applying solid phase extraction with RP-C18 material. Analyst 124: 473-475. http://dx.doi org/10.1039/a 809724K.

25. Tiwari, P.; P. Naithani and J.K. Tiwary (2016). Determination of heavy metals in honey samples from sub-montane and montane zones of Garhwal Himalaya (India). World J. of Pharmacy and Pharmecutical Sci., 5 (7): 812-819.

26. Tuzen, M. and M. Soylak (2005). Trace heavy metal levels in microwave digested honey samples from Middle Anatolia, Turkey. Journal of Food and Drug Analysis, 1: 343-347.

27. Vanhanen, L.P.; A. Emmertz and G.P. Savage (2011). Mineral analysis of mono-floral. New Zealand honey. Food Chem., 128: 236-40.

28. WHO (1982). Evaluation of certain food additives and contaminants. Twenty-sixth report of the joint FAO/WHO Expert Committee on Food Additives. Technical Report Series 683. Geneva. 